\section{$2 \mathrm{P329}$}

視交叉上核のリズム発掁機構の構成的および分析的 研究手法の開発

○杉尾 嘉宏 ${ }^{1}$ 、寺薄 英之 ${ }^{2}$ 、鈴木 郁郎 ${ }^{1}$ 、金子智行 ${ }^{1}$ 、神保 泰彦 3 、安田 㹂二 ${ }^{1}$ ( 1 東大院・総合文化・生命、 ${ }^{2}$ 長崎大・ 医学部・第 2 生理、 3 東大院・工学系・精密機械工学)

哺乳類においては、自律神経系の中枢である視床下部の前部神経核である視 交叉上核 (SCN) が、サーカディアンリスムの中枢であることが知られてい る。分散培養した SCN 神経細胞は、発火頙度に関して、個々の細胞毎に固 有の周期と振動位相を持つサーカディアンリズムを示すことが報告されてい たが (David et al., Neuron, 14 (1995) 697-706)、その神経回路綃の多点同 時計测により取得した発火頻度の時間推移を調べると、発火の㠵進時期は細 胸間で同調することが新たに発見された (Shirakawa et al., Eur.J.Neurosci., $12(2000)$ 2833-2838)。このことは SCN 神経緗胞間で同謂したリズム振動 を発振するために、シナプスなどの細胞間結合を介しての、振勘位相に関 する情報のやり取りが必要であるとともに、粠成絊胞数や細胞の空間配固 パターンが重要な情報を担うことを強く示唆しているが、その機構の詳細 は未だ明らかになっていない。

本研究では、SCNを組樴レべルから分析的に理解すると同時に、あわせて 1 細胞レベルで構成的にネットワークを再構箱し、それを計测対象とするこ とで、神経ネットワークとしての集団奻果を相㭪的に理解することにつなが る実㖷アプローチの方法論の開発を目的とした。具体的には、多電極基板上 に培羬された SCN スライス切片へのレーザー照射による、段階的部分組織

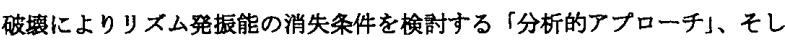
て神経細胞を格子状に 1 個ずつ並へ、細胞数、ネットワークの空閒配睥を完 全に制御した楎成的培養による 1 細胞レベル神経回路絴を計測対象として、 リスム発振能の獲得条件を検璟する「構成的アプローチ」という双方向性 をもった実䮊を同時に進めた。棈成的神経回路網の活動電位を計测するた めに、神経突起の伸长方向を制御することができるアガロースの微練楧造 を加工した多電極基板を用いた。

Y.Sugio, H.Terazono, I.Suzuki, T.Kaneko, Y.Jimbo, K.Yasuda Development of complementary approach for circadian rhythm of suprachiasmatic nucleus

\section{P331}

\section{椱製反応の実時間電気化学モニターによるDNA シー ケンサの検討}

○飯塚 毅、富田 允、田中 寿幸、金村 隆広、伏見 譲（埼玉 大.I)

本研究の目的は、DNA ポリメラーゼによる複製反応に伴う水素イ オン浪度変化を、ISFET(Ion Sensitive Field Effect Transistor)pH ンサにより実時間モニターすることを基砶とする小型高速 DNA シー ケンサの開発である。 ISFETpHセンサのゲート表面に、タグ配列 付ステムループプローブDNA(Buoy DNA)をSS 結合で固定化し、未 知配列を含む、セルフプライミングー本鎖 DNA(ターゲットDNA)の 5 ' 末端夕グ配列をハイブリダイゼーションさせる。そこにDNA ポ リメラーゼとともに 4 種の dNTPを順次流すことで、どの塩基を流し たときに DNA 伸長反応が起こるかを ISFET からの電気的な出力と して検知する。この方法は大規模並列処理に適している。Buoy DNA 固定化は、基板にメルカプト基を遒入し、ループ部分に thio-dU を持 たせることで、ジスルフィド結合により行った。複製反応をフロー系 で行ったところ 20 塩基分の複製反応を観測できた。現在は、1 塩基 複製反応を観測するためにフロー系の改良中である。室温、相対湿度

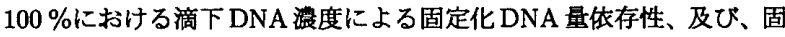
定化反応時間による固定化 DNA 量依存性を調查して Buoy DNA の 固定化反応を最適化し、DNA 複製反応の条件と ISFET $の \mathrm{pH}$ 応答加 ら決まる㭘出限界固定化量 [103molecules $/ \mu \mathrm{m} 2]$ の、10 倍の固定化 量を得た。

T.Iizuka,M.Tomita,T.Tanaka,T.Kanemura and Y.Husimi : Towards a fast small DNA sequencer using real-time electrochemical monitoring of DNA replication reaction

\section{P330}

赤血球ゴーストの誘電分散シミュレーション

○浅見 耕司（京大・化研）

生物細胞や組織の誘電率を広い周波数領域にわたって測定すると、低 周波側から， $\alpha-、 \beta-\gamma$-の 3 つの誘電分散が見られる。 $\gamma$-分散は 水分子の分極。 $\beta$-分散は通常 $10 \mathrm{kHz}$ 以上で見られ、界面分極（ま たは Maxwell-Wagner 効果) による。 $\alpha$-分散は $10 \mathrm{kHz}$ 以下で観測さ れ、その分極機構として、細胞内膜系（笳肉）やイオンのダーティン グ (神経，筋肉）に関連した分極、あるいは荷電細胞表面での対イオ ン分極などが考えられている。しかし、低周波での測定が困難である こともあって、この分極機構の解明は充分なされていない。Schwan \& Carstensen (1957) は、赤血球を蒸留水で溶血させた ghostについ て、 $\beta$-分散に加えて、' $\alpha$-分散'を報告している。（正常赤血球では $\alpha$-分散は観測されない。）この' $\alpha$-分散”の分極機構については、上 で述べたものは当てはまらず、いまだ解明されていない。今回、この “ $\alpha$-分散 'について、重要な手がかりが得られたので報告する。赤血 球を溶血させると、膜に大きな穴が開き、へモグロビンのような高 分子でも透過できるようになる。条件によって、その穴は再び閒じる か、あるいは長時間開いた状態にある。そこで、膜に一つの穴をもつ 球形細胞モデルいいて、3次元の差分法を用いて、界面分極による 誘電分散の数值計算を行った。その結果、穴の面が電極に対して垂直 にあるときには、穴が無い場合とほとんど同じ誘䉓分散スペクトル示 したが、平行になると、整いたことに，低周波側にもう一つ分散が現 れた。この低周波の分散は ghost の ' $\alpha$-分散”に大变良く似ていた。 このことは, ghostの ' $\alpha$-分散”は, 細胞膜に一個の穴をもつとする と，界面分極で説明ができることを示している。

K. Asami : Dielectric dispersion of lysed erythrocytes

\section{P332}

\section{近赤外脳機能計測における}

波長差分法を用いたベースライン安定化の試み

○山田 亨、梅山伸二（産総研 脳神経情報）

近赤外分光法 (NIRS)により酸素結合型および酸素脱離型へモグロ

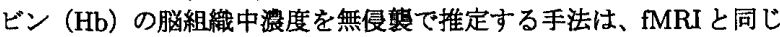
く脳活動に伴う酸萦代謝をモニターでき、かつサブ秒以下の時間分解 能をもち、電磁的ノイズへの耐性が高く、被蹹者への拘束性が低いこ とから近年注目を集めている。

しかしながら、NIRSによる各 $\mathrm{Hb}$ 港度推定值は従来、脳機能活動 に起因しない各種の変動成分の混在が指摘されてきた。これらには 心拍、呼吸など生理佸動に同期した成分および頚部や顎部の運動、プ ローブの摇れに起因する成分などが上げられる。今回、我々はこれら の变動成分の混入の機序を考察し、波長差分法を用いることでこれら の変動の低減効果が得られるを見出したので報告する。

まず壊度推定に通常用いられる2成分モデルの妥当性の検討を行っ た。 2 成分モデルでは 2 点の観測波長での吸光度変化から modified Lambert-Beer 則に基づき各 $\mathrm{Hb}$ 潧度変化を推定する。モデルが妥当 であれば、近接する複数の波長ペアでの測定に基つく複数の推定結果 はすへてて致するはずである。しかし 3 波長の吸光度測定から得られ る3つの推定結果は一票していないことが分かった。

そこで独立に時間変動する非波長依存性の第 3 成分を遒入してモデ ルを改良した。非波長依存性は生体組織の光散乱や信号処理系での雑 音の混入などを考慮する上で妥当な条件と考えられる。このような第 3 成分の除去に対して波長差分法は有効な方法である。3波與での吸 光度変化量の各波長間での差分量を用いて各 $\mathrm{Hb}$ 浀度の時間変化を推 定し、従来法と比較した。その結果、安静時の各 $\mathrm{H} \mathrm{b}$ の時間変化は 長周期変動が揤えられ、より平坦化することが分かった。パワースペ クトル上でも従来法で見られる心拍・呼吸由来の変動成分がこの方法 により除去できることが分かった。

T.Yamada S.Umeyama : Stabilzation of the baseline drift on brain activity observation by NIRS using wavelength differential method. 